\title{
MEN1, MEN4, and Carney Complex: Pathology and Molecular Genetics
}

\author{
Marie Helene Schernthaner-Reiter Giampaolo Trivellin Constantine A. Stratakis \\ Section on Endocrinology and Genetics, Eunice Kennedy Shriver National Institute of Child Health and Human \\ Development, National Institutes of Health, Bethesda, Md., USA
}

\section{Key Words}

Multiple endocrine neoplasias - Pituitary adenomas .

Pituitary hyperplasia $\cdot$ Protein kinase A $\cdot$ Menin $\cdot$ Genetics

\begin{abstract}
Pituitary adenomas are a common feature of a subset of endocrine neoplasia syndromes, which have otherwise highly variable disease manifestations. We provide here a review of the clinical features and human molecular genetics of multiple endocrine neoplasia (MEN) type 1 and 4 (MEN1 and MEN4, respectively) and Carney complex (CNC). MEN1, MEN4, and CNC are hereditary autosomal dominant syndromes that can present with pituitary adenomas. MEN1 is caused by inactivating mutations in the MEN1 gene, whose product menin is involved in multiple intracellular pathways contributing to transcriptional control and cell proliferation. MEN1 clinical features include primary hyperparathyroidism, pancreatic neuroendocrine tumours and prolactinomas as well as other pituitary adenomas. A subset of patients with pituitary adenomas and other MEN1 features have mutations in the CDKN1B gene; their disease has been called MEN4. Inactivating mutations in the type 1 a regulatory subunit of protein kinase $\mathrm{A}$ (PKA; the PRKAR1A gene), that lead to dysregulation and activation of the PKA pathway, are the
\end{abstract}

main genetic cause of $\mathrm{CNC}$, which is clinically characterised by primary pigmented nodular adrenocortical disease, spotty skin pigmentation (lentigines), cardiac and other myxomas and acromegaly due to somatotropinomas or somatotrope hyperplasia.

(c) 2015 S. Karger AG, Basel

\section{Introduction}

About $5 \%$ of pituitary adenomas (PAs) occur in a familial setting [1]. The majority of these familial pituitary tumours are due to multiple endocrine neoplasia (MEN) type 1 (MEN1) [2]. Other genetic causes include Carney complex (CNC), MEN4, mutations in the aryl hydrocarbon receptor interacting protein $(A I P)$ gene leading to familial isolated PAs (FIPAs) and McCune-Albright syndrome (MAS). Recently, mutations in succinate dehydrogenase subunits (SDHX) and DICER1 as well as Xq26.3 microduplications have also been associated with pituitary tumours. Genetic conditions (germline or somatic) leading to pituitary tumours are summarised in table 1.

Despite the relative rarity of syndromic PAs, the study of their genetic causes has contributed significantly to the understanding of pituitary tumourigenesis in general.

\section{KARGER}

E-Mail karger@karger.com

www.karger.com/nen
(C) 2015 S. Karger AG, Base

0028-3835/15/1031-0018\$39.50/0
Dr. Marie Helene Schernthaner-Reiter SEGEN, PDEGEN, NICHD, NIH

10 Center Drive, Building 10, NIH Clinical Research Center

Room 1-3330, MSC1103, Bethesda, MD 20892-1862 (USA)

E-Mail helene@schernthaner.eu 
MAS and CNC are caused by mutations in members of the cAMP-dependent protein kinase (protein kinase A, PKA) pathway [3, 4]; similarly, the PKA pathway, which contributes to pituitary proliferation and hormone secretion, is also altered in approximately $40 \%$ of sporadic somatotropinomas [5-10].

On the other hand, no single consistent genetic mechanism for pituitary tumourigenesis has emerged yet. Classic tumour suppressor genes, such as TP53 or RB1, or oncogenes, including HRAS, are all involved in but not thought to be major contributors to germline predisposition to pituitary tumourigenesis [11-14]. MEN1 and $C D K N 1 B$, whose mutations can cause pituitary tumour formation in the context of MEN syndromes, were shown to be mutated or down-regulated only in few sporadic tumours [15-19]. Similarly, mutations in AIP and PRKA$R 1 A$, which lead to familial pituitary tumours in the context of FIPA and CNC, respectively, do not seem to contribute significantly to sporadic pituitary tumours $[10$, 20-24], although AIP expression is reduced in some sporadic somatotropinomas in the absence of AIP mutations [25], probably due to the actions of different microRNAs $[26,27]$. The variable and incomplete penetrance of these hereditary pituitary tumour syndromes suggests that additional circumstances are required for pituitary tumourigenesis. These have not been clearly defined yet, even though some candidate loci have been reported for $A I P$-associated tumours $[28,29]$, and a possible association was suggested between a $C D K N 1 B$ variant and tumour multiplicity in MEN1 [30]. However, these additional circumstances required for pituitary tumourigenesis in the context of genetic syndromes may well involve the same pathways controlling cell proliferation and hormone secretion that are also dysfunctional in sporadic PAs.

MAS is a genetic but not hereditary condition caused by somatic, postzygotic mutations in the $\alpha$-subunit of the $\mathrm{G}_{\mathrm{s}}$ protein (GNAS), leading to somatotrope or somatolactotrope hyperplasia and growth hormone $(\mathrm{GH})$ hypersecretion in approximately $20 \%$ of patients $[3,31$, 32]. Inactivating germline mutations in AIP were recently discovered to be the genetic cause in about $20 \%$ of FIPA patients [33]. These patients have mostly somatotropinomas or prolactinomas (and sometimes nonfunctioning PAs and rarely corticotropinomas), and no other recurrent clinical manifestations [33, 34]. MAS, FIPA due to AIP mutations and their contribution to pituitary pathology are described in detail elsewhere [3, 31-34]. Mutations in different subunits of $S D H$ can lead to hereditary pheochromocytoma and paraganglioma

MEN1, MEN4, and Carney Complex:

Pathology and Molecular Genetics syndromes [35], and, recently, $S D H x$ mutations have also been reported to be associated with PAs [36-40]. Pituitary blastoma, manifesting mostly in early childhood and leading to Cushing's syndrome, has recently been described [41, 42]. Germline mutations in DICER1 were reported in almost all cases of pituitary blastoma [41-43]; interestingly, germline DICER1 mutations also cause other early childhood tumours summarised as pleuropulmonary blastoma-familial tumour and dysplasia syndrome (table 1). However, in the few cases that have been reported, the manifestation of another DICER1-related tumour in association with pituitary blastoma is rare [43].

We have recently reported $\mathrm{Xq} 26.3$ microduplications in association with early childhood-onset gigantism, termed X-linked acrogigantism (X-LAG) [44]. This is probably due to overexpression of GPR101, a G-protein coupled orphan receptor that is located in this region, and downstream PKA pathway activation; interestingly, a recurring GPR101 variant is found in some cases of sporadic acromegaly [44]. A possible association was suggested between neurofibromatosis type 1 and acromegaly or gigantism in a few case reports [45]; this GH excess is due to optic pathway tumours that are hypothesised to suppress hypothalamic somatostatin secretion, and hence will not be discussed in detail here.

In this review, we present an update on the clinical manifestations and human molecular genetics of three of the above referenced diseases, all caused by genetic defects in the germline, MEN1, MEN4 and CNC.

\section{Multiple Endocrine Neoplasia Type 1}

MEN1 (MIM 131100) is an autosomal dominant disorder, leading to parathyroid neoplasms, pancreatic neuroendocrine tumours (PNETs) and PAs [46]. Other MEN1-associated endocrine and nonendocrine neoplasms, including adrenocortical tumours, carcinoids and facial angiofibromas, may also occur $[46,47]$. The prevalence of MEN1 is about 1:30,000 [46], but geographical clustering due to a founder effect can be observed [48, 49]. There is considerable phenotypic variability of tumour type manifestations even within the same family [50], suggesting the possible involvement of modifier genes or epigenetic changes.

The penetrance of MEN1 is generally high, with biochemical signs present in $>95 \%$ and clinical signs in $80 \%$ of patients by the 5th decade of life [50-52]; for instance, the age-related penetrance at 50 years is $73-75 \%$ for pri- 
Table 1. Genetic conditions that lead to pituitary adenomas

\begin{tabular}{|c|c|c|c|}
\hline & Genetic cause & General pathology & Endocrine pathology \\
\hline MEN1 & MEN1 (>80\%) & $\begin{array}{l}\text { Facial angiofibromas } \\
\text { Collagenomas } \\
\text { Lipomas }\end{array}$ & $\begin{array}{l}\text { PHPT } \\
\text { PNETs } \\
\text { PAs (mostly prolactinomas) }\end{array}$ \\
\hline $\mathrm{CNC}$ & PRKAR1A (>70\%) & $\begin{array}{l}\text { Myxomas (cardiac, cutaneous, } \\
\text { mammary) } \\
\text { Lentigines }\end{array}$ & $\begin{array}{l}\text { PPNAD } \\
\text { Gonadal tumours } \\
\text { Thyroid tumours } \\
\text { Acromegaly (somatolactotrope hyperplasia) }\end{array}$ \\
\hline MEN4 & CDKN1B (>90\%) & Uterine tumours & $\begin{array}{l}\text { PHPT } \\
\text { PAs (corticotropinomas, somatotropinomas, } \\
\text { nonfunctioning PAs) } \\
\text { Adrenocortical tumours } \\
\text { Thyroid tumours } \\
\text { Gastrointestinal neuroendocrine tumours }\end{array}$ \\
\hline FIPA & $A I P$ (approx. 20\%) & None & PA (mostly somatotropinomas) \\
\hline $\begin{array}{l}\text { Familial pheochromocytoma/ } \\
\text { paraganglioma syndromes }\end{array}$ & SDHx (approx. 40\%) & & $\begin{array}{l}\text { Paraganglioma } \\
\text { Pheochromocytoma } \\
\text { PA }\end{array}$ \\
\hline $\begin{array}{l}\text { DICER1 syndrome (pleuropulmonary } \\
\text { blastoma-familial tumour and } \\
\text { dysplasia syndrome) }\end{array}$ & DICER1 (>90\%) & $\begin{array}{l}\text { Pleuropulmonary blastoma } \\
\text { Cystic nephroma } \\
\text { Embryonal rhabdomyosarcoma }\end{array}$ & $\begin{array}{l}\text { Pituitary blastoma (Cushing's syndrome) } \\
\text { Sertoli-Leydig cell tumour } \\
\text { Multinodular goiter }\end{array}$ \\
\hline X-linked acrogigantism (X-LAG) & $\begin{array}{l}\text { Xq26.3 microduplication } \\
(100 \%)\end{array}$ & & $\begin{array}{l}\text { Gigantism (early childhood onset } \\
\text { somatotropinoma or somatotrope hyperplasia) }\end{array}$ \\
\hline
\end{tabular}

mary hyperparathyroidism (PHPT), 31-48\% for PAs and for $45-49 \%$ islet cell tumours $[52,53]$. However, the age at presentation of specific tumour types is highly variable and may range from 9-25 years for the earliest to 68-77 years for the latest tumour manifestation [52]. MEN1 patients have a decreased life expectancy, and MEN1-associated mortality is mostly due to enteropancreatic malignancy [52-56]. MEN1-associated mortality has improved since the 1980s due to more intense screening programs, better perioperative survival and, since protein pump inhibitors became available, reduced mortality due to gastrinoma-associated gastric ulcer perforation and haemorrhage [55].

\section{Primary Hyperparathyroidism}

PHPT is frequently the presenting feature of MEN1 [50] and also the most common MEN1-associated clinical manifestation that occurs in more than $90 \%$ of mutation carriers [47, 50, 52]. MEN1-associated PHPT develops approximately 30 years earlier than sporadic
PHPT and has an almost even gender ratio, whereas sporadic PHPT has a $75 \%$ female preponderance [57]. PHPT in the context of MEN1 is associated with higher severity of bone involvement with borderline rather than elevated parathyroid hormone levels and only mildly elevated serum calcium [58]. Usually, MEN1associated PHPT is due to multiglandular hyperplasia, whilst there is more often one evident adenoma in sporadic PHPT [59-62]. Consequently, surgery is often more challenging, involving the intraoperative identification and removal of all four glands, and recurrence rates are high $[63,64]$. In addition, supernumerary or ectopic parathyroid glands occur in up to $20 \%$ of patients [60], and their identification is crucial to prevent recurrence. In conjunction with open bilateral neck exploration, total thymectomy is also often performed since this is the most common location for ectopic parathyroid glands; intraoperative parathyroid hormone measurement can aid to determine the successful removal of all overactive glands [65]. 


\section{Pancreatic Neuroendocrine Tumours}

PNETs are also a frequent feature of MEN1 in up to $75 \%$ of patients $[47,50,52]$, but patients are often asymptomatic and the real prevalence may be higher $[47,66]$. These tumours are most often gastrinomas, insulinomas or nonfunctioning PNETs, occasionally glucagonomas, VIPomas or somatostatinomas [47, 52, 55]. Most MEN1 patients have multiple microadenomas in the pancreas and duodenum, only few of which become clinically relevant [67,68]; consequently, metastases are frequently present $(30-50 \%)$ at the time of symptom appearance [68, 69]. Gastrinomas associated with excessive gastric acid production and gastric ulceration, referred to as ZollingerEllison syndrome, are a major contributor to MEN1-associated mortality $[49,70]$. MEN1-associated gastrinomas are usually located in the duodenum, and are small and multicentric compared to the larger and mostly singular sporadic gastrinomas [71-73]; consequently, the surgical resection of a single tumour is not likely to be curative, and therapy of small nonmetastatic tumours is primarily symptomatic [47]. Importantly, gastrinomas are relatively rare in the general population, and $20 \%$ of patients with gastrinomas have MEN1 [73]. Nonfunctioning PNETs have recently attracted attention due to the finding that their prevalence and associated mortality are higher than previously thought $[55,74]$. Their prognosis is worse than that of functioning PNETs, and clinical assessment is difficult due to the absence of specific symptoms or biochemical markers [55, 74]. Insulinomas are the first manifestation of MEN1 in $10 \%$ of patients, and even though there is often more than one tumour, surgery is recommended [65]. VIPomas, glucagonomas and somatostatinomas are rare; however, if present, they have a high risk of malignancy $[68,75]$, and surgery should be performed in the absence of distant metastases [75].

\section{Pituitary Adenomas}

The frequency of PAs in MEN1 is around 40\% depending on the patient population $[47,50,52,76]$; conversely, only $3 \%$ of patients with PA have MEN1 [2]. The mean age at presentation is around 38 years, but can vary between 5 years and the 9th decade of life $[76,77]$. PAs are the first MEN1 manifestation in about $20 \%$ of patients $[53,76]$. PAs are most commonly prolactinomas, followed by nonfunctioning PAs, somatotropinomas and corticotropinomas; this distribution is approximately the same as that seen in sporadic PAs. However, in MEN1 PAs, there is a higher incidence of multiple hormone expression and multiple adenomas $[76,78]$. MEN1-associ- ated PAs are more aggressive than sporadic PAs, they are macroadenomas in $85 \%$ of cases compared to $40 \%$ in sporadic PAs, and they may infiltrate surrounding tissues more frequently $[76,78]$. This is accompanied by a worse rate of hormonal control in MEN1 PAs [76]: 44\% of MEN1-associated prolactinomas are resistant to dopamine agonist therapy $[76,79]$. The presence of pituitary enlargement in imaging studies does not preclude elevated hormone production elsewhere, and in rare cases, PNETs that secrete hypothalamic hormones and lead to excessive secretion of pituitary hormones have been encountered [78, 80, 81]. Sporadic PAs and MEN1 PAs are similarly more common in females than in males (approx. $70 \%$ females in MEN1 patients). There is currently no explanation for this, although oestrogen was hypothesised to stimulate the proliferation of pituitary cells, as seen experimentally $[76,82]$.

\section{Other MEN1-Associated Features}

Approximately $40 \%$ of MEN1 patients develop additional functioning or nonfunctioning endocrine tumours [52]. Most commonly, these are benign nonfunctioning adrenocortical lesions, but primary aldosteronism, adrenocorticotropic hormone (ACTH)-independent Cushing's syndrome or, more rarely, adrenal hyperandrogenism due to adrenal adenomas are found in about $15 \%$ [83]. This is significantly higher than the rate of endocrine activity among sporadic adrenal incidentalomas, indicating that adrenocortical tumours or bilateral hyperplasia in MEN1 are frequently functioning [83]. Facial angiofibromas occur in up to $88 \%$ of patients and collagenomas in up to $72 \%[84,85]$, and their presence may aid diagnosis (the presence of three facial angiofibromas and one collagenoma is $75 \%$ sensitive and $95 \%$ specific for MEN1) [85]. Pheochromocytoma is rarely observed (approx. 1\%) [83]. Interestingly, MEN1 patients have impaired fasting glucose (17 vs. $6 \%$ in controls) that cannot be adequately explained by the presence of hormonesecreting tumours or previous pancreatic surgery, and may contribute to cardiovascular mortality $[86,87]$.

\section{Molecular Genetics}

The genetic cause of MEN1 was initially localised to $11 \mathrm{q} 13$ and later identified as the tumour suppressor gene MEN1, which consists of 10 exons and codes for the protein menin [88-90]. Loss of heterozygosity of the MEN1 locus is frequently found in MEN1 tumours [88, 91, 92].

Menin is a 610 amino acid protein with no homology to other known proteins. Its expression is ubiquitous and the mechanism of how loss of function of menin leads to 
MEN1 is still unclear [89, 90, 93]. Menin predominantly localises to the nucleus, containing two classical nuclear localisation signals and at least one further nonclassical nuclear localisation signal in its C-terminus [94, 95]. In the nucleus, it can associate with chromatin [96], dsDNA [97], the lysine-specific histone methyltransferases KMT2A and KMT2B $[98,99]$ and components of a transcriptional repressor complex also including histone deacetylases [100]. Menin interacts with transcription factors including activating protein-1, JunD, nuclear factor- $\kappa \mathrm{B}, \beta$-catenin, mothers against decapentaplegic (SMAD) family members and oestrogen receptor $\alpha(E R \alpha)$ [98, 101-107]. Menin binds to cytoskeletal proteins, e.g. vimentin [108], and cytoplasmic cell signalling mediators including Akt1/PKB and forkhead box protein $\mathrm{O} 1$ (FoxO1) $[109,110]$. Some of the known menin interaction partners are depicted in figure 1. Menin was shown to play a role in cell proliferation [111-113], apoptosis $[114,115]$ and genome integrity [116]. Menin and KMT2A in complex regulate the expression of several Hox genes as well as $C D K N 1 B$, and they interact with ERa to coactivate ER $\alpha$-mediated transcription $[98,107,117$, 118]. Interestingly, chromosomal rearrangements involving KMT2A lead to mixed-lineage leukaemia, and in this context, menin was shown to be required for KMT2A-dependent oncogenic transformation [119]. This illustrates the functional versatility of menin in different tissues that may also help to understand the yet unexplained tissue selectivity of MEN1-associated tumours even in the presence of the same mutation.

Hundreds of MEN1 mutations have been described, which are located along the whole coding region and splice sites of the gene [120]. While most MEN1 cases are familial, $10 \%$ of cases occur in a nonfamilial context and are due to de novo MEN1 mutations [120]. The majority of mutations leading to MEN1 are frameshift deletions or insertions and nonsense mutations leading to truncation or absence of the protein $[52,120]$. Missense mutations leading to single amino acid substitutions were assumed to cause less severely impaired protein function, but no notable difference was observed in the clinical manifestation of those patients [52]. Some mutations leading to single amino acid substitutions were demonstrated to lead to proteasomal degradation and hence markedly reduced protein levels [121], while other mutations lead to nonsense-mediated mRNA decay [122]. A reduction of the interaction capacity of menin with its binding partners was also shown for some mutations leading to single amino acid substitutions $[98,101]$. Some intronic mutations were demonstrated to lead to alternative splicing,

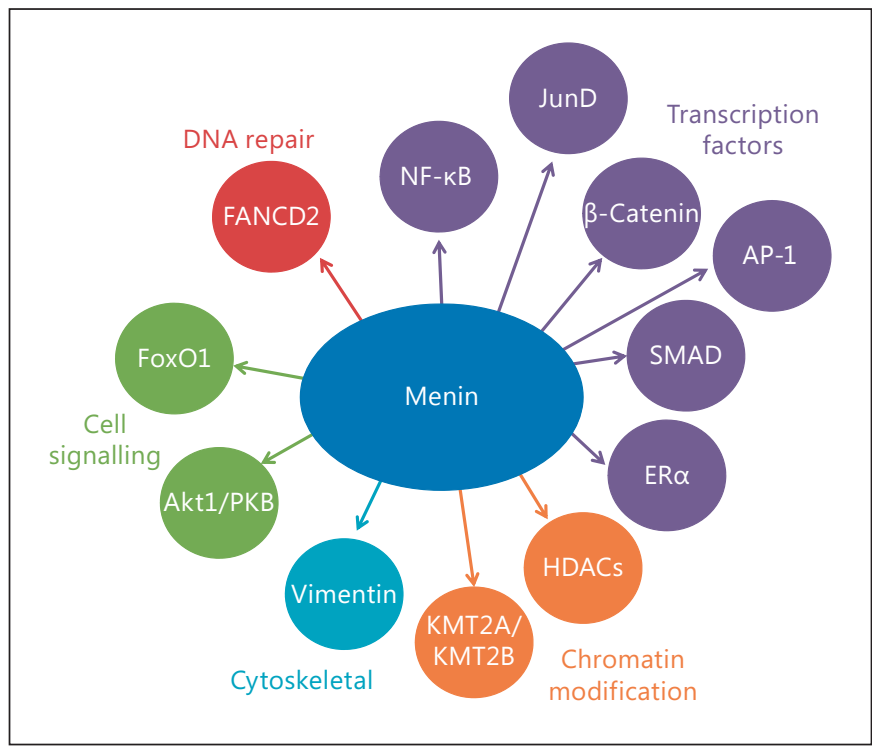

Fig. 1. Interacting partners of menin. Menin interacts with transcription factors including nuclear factor $-\kappa B(N F-\kappa B)$, JunD, $\beta$-catenin, activator protein-1 (AP-1), mothers against decapentaplegic (SMAD) family members and ERa; with proteins regulating chromatin structure including histone deacetylases (HDACs) and the histone methyltransferases KMT2A and KMT2B; with cytoskeletal proteins such as vimentin; with cytoplasmic cell signalling mediators including forkhead box protein $\mathrm{O} 1$ (FoxO1) and Akt1/PKB, and with DNA repair proteins including Fanconi anaemia group D2 protein (FANCD2).

suggesting that they are causative for MEN1 [123-125]. Interestingly, in approximately $10 \%$ of patients with clinical MEN1, no MEN1 gene mutations could be identified $[120,126-128]$. In a small number $(1 \%)$ of these cases, large deletions of one exon or more could be detected using multiple ligation-dependent probe amplification (MLPA) or long-range PCR amplification [129, 130]. In the remaining cases, the phenotype may be due to intronic mutations that are not detected by routine sequencing; however, the involvement of mutations in other genes cannot be excluded.

\section{Genotype-Phenotype Correlation}

Due to the large number of different mutations in combination with the heterogeneity of disease manifestations it has proved difficult to establish subtle genotypephenotype correlations in MEN1. One study found that all patients with frameshift mutations have PNETs [131], while another study showed a higher rate of malignant tumours for mutations in MEN1 exons 2, 9 and 10 [132]. However, no genotype-phenotype correlation could be 
consistently confirmed in different patient populations $[52,120]$. In addition, studies of unrelated kindreds with the same mutation showed a large variability of different MEN1-associated tumours [51, 133], and there are reports of identical twins with different MEN1 manifestations [134-136]. Remarkably, some families with particular MEN1 mutations develop only isolated hyperparathyroidism, while the same mutations in other families lead to full MEN1 [120]. Epigenetic mechanisms caused by environmental factors may influence disease phenotype in patients carrying the same MEN1 mutation [137]. Recently, a specific variant of the CDKN1B gene was demonstrated to be disease modifying in MEN1 patients with truncating MEN1 mutations, causing a higher number of MEN1 related tumours [30].

\section{Multiple Endocrine Neoplasia Type 4}

In the approximately $10 \%$ of patients with a MEN1like phenotype in whom no MEN1 mutations could be detected, other genes were suspected to be responsible for the clinical manifestation [120,126-128]. A rat model displaying a MEN1-like phenotype was discovered to harbour a mutation in the $C D K N 1 B$ gene, leading to premature termination [138]. CDKN1B transcription is regulated by menin $[117,139]$. CDKN1B encodes for the cyclin-dependent kinase inhibitor $\mathrm{p} 27^{\mathrm{Kip} 1}$, which participates in cell cycle regulation by interacting with cyclindependent kinases [140], and in turn, p2 $7^{\text {Kip }}{ }^{1}$ levels are regulated via the mitogen-activated protein kinase (MAPK) and the phosphatidyl inositol-3 kinase (PI3K) pathways $[141,142]$. In a small number (up to $3 \%$ ) of MEN1 mutation-negative patients fulfilling the diagnostic criteria for MEN1, mutations in CDKN1B have been detected, and the corresponding clinical syndrome has been termed MEN4 (MIM 610755) [138]. Mutations in some of those patients were shown to either lead to decreased cellular levels of $\mathrm{p} 27^{\mathrm{Kip} 1}$ by reduced translation or proteasomal degradation, or to functional defects causing reduced binding to interacting partners or decreased nuclear localisation [138, 143-145]. Interestingly, a novel mechanism of CDKN1B loss of function leading to MEN4 was recently discovered: a 4 bp deletion in an upstream ORF within the CDKN1B 5'UTR led to decreased translation reinitiation and decreased p27 ${ }^{\text {Kipl }}$ levels [146].

PHPT is present in all the MEN4 patients reported so far, but the clinical and histological manifestations seem to be more variable than in MEN1, and due to the small number of patients so far reported, a comprehensive phenotype

MEN1, MEN4, and Carney Complex:

Pathology and Molecular Genetics has not yet been established [147]. PAs (corticotropinomas, somatotropinomas and nonfunctioning PAs) as well as neuroendocrine tumours, uterine neoplasms, adrenocortical masses and thyroid tumours have also been described in the MEN4 context [138, 143-145, 148].

\section{Carney Complex}

CNC (MIM 160980) is a rare endocrine tumour syndrome with currently about 750 documented cases worldwide $[149,150]$. Initially described as the complex of myxomas, spotty skin pigmentation (lentigines) and endocrine overactivity, the familial syndrome is inherited in an autosomal dominant fashion [151, 152]. Further manifestations include primary pigmented nodular adrenocortical disease (PPNAD) leading to Cushing's syndrome, PAs, thyroid nodules, testicular neoplasms, ovarian cysts, psammomatous melanotic schwannomas, ductal breast adenomas and osteochondromyxomas [153]. Most CNC patients initially present with ACTH-independent Cushing's syndrome due to PPNAD or heart myxomas, although abnormal skin pigmentation may be present at birth and is most often the first manifestation [153-155]. The majority of $\mathrm{CNC}$ cases are caused by inactivating germline mutations in the type $1 \alpha$ regulatory subunit (R1a) of PKA (PRKAR1A) gene [156], and those mutations lead to CNC with a penetrance close to $100 \%$ [149, $150]$. About $70 \%$ of $\mathrm{CNC}$ cases occur in a familial context [149].

\section{Cushing's Syndrome due to PPNAD}

PPNAD is most frequently seen in the context of CNC, and $60 \%$ of CNC patients have PPNAD [149, 157]. Conversely, of all patients with PPNAD, about $80 \%$ have CNC, while $20 \%$ have isolated PPNAD, where no other CNC-associated lesions could be detected [149]. PPNAD typically manifests at a young age (median age 34 years) and leads to ACTH-independent adrenocortical Cushing's syndrome [149]. Diagnosis can be challenging in cases of cyclical (14\%) or subclinical Cushing's syndrome (19\%) [157]. It should be noted that most CNC patients with PPNAD have a paradoxical increase of cortisol secretion after dexamethasone administration, which is diagnostically particularly useful in patients with normal baseline cortisol levels [157].

\section{Pituitary Adenomas}

While approximately $75 \%$ of CNC patients have abnormal GH, insulin-like growth factor 1 (IGF-1) or pro- 
lactin levels basally or during dynamic testing, PAs can only be detected in about $10 \%[149,153,158,159]$. This may be due to prolonged periods of somatolactotrope hyperplasia preceding adenoma formation [153, 159-161]. CNC-associated PAs are mostly positive for $\mathrm{GH}$ or $\mathrm{GH}$ and prolactin and can lead to acromegaly or gigantism and, rarely, to clinically significant hyperprolactinaemia $[152,158-162]$. A minority of adenomas also stained positive for thyroid-stimulating hormone, luteinising hormone or $\alpha$-subunit $[160,162]$, but these do not cause a clinical phenotype. CNC-related adenomas are often multiple, surrounded by hyperplasia and mostly microadenomas, but there are also cases of very aggressive and invasive macroadenomas [160].

\section{Cardiac Myxomas}

CNC-associated cardiac myxomas can be found in $30 \%$ of CNC patients [149]. They have an even age and gender distribution and occur anywhere in the heart, as opposed to sporadic cardiac myxomas, which more frequently occur in the left atrium and in older females [153]. Tumours can be multiple and can recur after removal [149]. The age at manifestation varies between 3 and 67 years [149]. Although these are benign neoplasms, they can lead to serious complications including cardiac insufficiency, stroke or pulmonary embolism [153].

\section{Skin Manifestations}

Lentiginosis (present in $70 \%$ of patients) and other pigmented cutaneous lesions (blue, Spitz and compound naevi and café-au-lait spots, 50\%) are frequently observed and may be present at birth or appear in early childhood $[149,153]$. Cutaneous myxomas are found in $20 \%$ of CNC patients [149]. Of affected women, $20 \%$ have mammary myxomas [149]. Other skin tumours include lipomas, collagenomas and ear canal trichofolliculoepitheliomas.

\section{Other CNC-Associated Tumours}

Psammomatous melanotic schwannomas are a relatively rare manifestation of $\mathrm{CNC}$; however, they cause significant morbidity and can even be the cause of death of CNC patients because they can (depending on their location) cause significant neurologic deficits, obstructive pulmonary disease or increased intracranial pressure. Finally, they can become malignant and, when they do, they are aggressive tumours with frequent lung or cerebral metastases [153].

Testicular neoplasms occur in more than one third of male patients (by ultrasonography) and are mostly large- cell calcifying Sertoli cell tumours [149]. Thyroid nodules can also be observed frequently, but thyroid cancer is rare [149]. Rarely, patients also develop ovarian cancer [163], liver cancer [164], and pancreatic neoplasms [165].

\section{Molecular Genetics}

The most frequent genetic cause (in about $73 \%$ of the patients) of CNC is a PRKAR1A defect $[4,149,166]$. PRKAR1A acts as a tumour suppressor by haploinsufficiency, although loss of the wild-type allele is also found in most CNC-associated tumours $[4,153,166]$.

PRKAR1A encodes for the R1 $\alpha$ of PKA. PKA is a heterotetramer composed of two catalytic subunits $(\mathrm{Ca}, C \beta$, $\mathrm{C} \gamma$ or $\mathrm{Cx})$ and two regulatory subunits $(\mathrm{R} 1 \alpha, \mathrm{R} 1 \beta, \mathrm{R} 2 \alpha$ or $R 2 \beta)$. Stimulation of the $G_{s}$ protein leads to the activation of adenylyl cyclase that produces cAMP. cAMP is then bound by PKA regulatory subunits, which leads to the activation of PKA by the dissociation of the regulatory subunits from the active sites of the catalytic subunits. The active catalytic subunits are then free to act as serine/ threonine kinases phosphorylating downstream targets both in the cytoplasm and in the nucleus. These downstream targets include CREB (cAMP responsive element binding protein), which in turn mediates CRE (cAMP responsive element)-dependent transcription (fig. 2a) [167, 168].

A reduction of $\mathrm{R} 1$ a levels therefore causes the disinhibition of PKA, leading to an increase of cAMP-stimulated PKA activity (fig. 2b) [4, 169-171]. R1a deficiency leads to a decreased SMAD3 expression, thereby reducing transforming growth factor $\beta$-mediated apoptosis in adrenocortical cells [172]. In addition, MAPK pathway activity was shown to increase in response to inactivating PRKAR1A mutations, causing increased cell proliferation $[169,173,174]$. R1 $\alpha$ deficiency also leads to an up-regulation of different components of the Wnt signalling pathway $[175,176]$. Interestingly, some CNC patients with PPNAD have somatic mutations in the $\beta$-catenin gene (CTNNB1) within the adrenal nodules, which is the main effector of the Wnt signalling pathway $[177,178]$.

More than 120 different PRKAR1A mutations have been identified to date in CNC patients $[149,156,166$, 171]. Sanger sequencing is used for the large majority of routine clinical sequence analysis, and, recently, large deletions have been identified in about $20 \%$ of those patients previously thought to be PRKAR1A mutation-negative by array-based comparative genomic hybridisation (aCGH) [179]. Almost all mutations generate a premature stop codon, either directly or by frameshift, leading to nonsense-mediated mRNA decay and absence of the R1a 
Fig. 2. The PKA pathway. a Ligand activation of the G-protein coupled receptor (GPCR) leads to activation of the stimulatory $G$ protein $\left(G_{s}\right)$ and its $\alpha$-subunit; this is followed by activation of adenylyl cyclase (AC). AC converts ATP into cAMP. In the basal state, PKA consists of two regulatory subunits (R) bound to two catalytic subunits (C). cAMP-binding to $\mathrm{R}$ causes the dissociation from $\mathrm{C}$, which is now free to act as a serine/threonine kinase. It can activate CREB by phosphorylation, which mediates transcription of genes with CREcontaining promoters. The PKA pathway contributes to the control of cell proliferation and differentiation, metabolism and hormone secretion. The phosphodiesterases (PDEs) hydrolyse cAMP, thereby reducing PKA pathway activity. b In CNC, $\mathrm{R} 1$ a levels are reduced, leading to increased PKA activation, reduced transforming growth factor $\beta$ (TGF $\beta$ )-mediated apoptosis, increased MAPK-dependent proliferation and a stimulated Wnt signalling pathway.
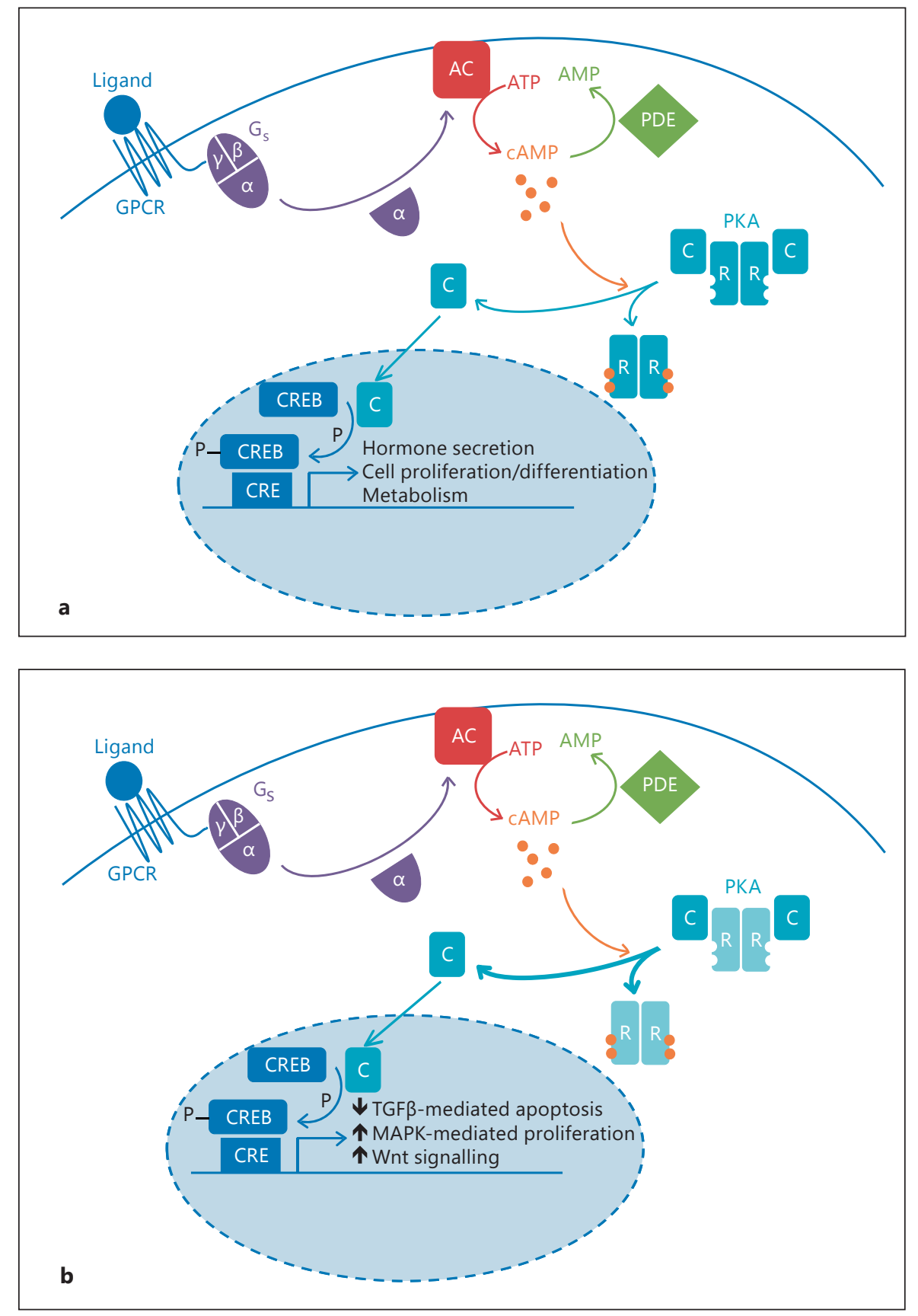

protein $[4,156]$, although some PRKAR1A mutations in $\mathrm{CNC}$ were demonstrated to lead to expressed $\mathrm{R} 1 \alpha$ that had lost its inhibitory effect on PKA signalling $[170,171]$.

\section{Genotype-Phenotype Correlation}

No obvious genotype-phenotype correlation could initially be detected in CNC patients with different PRKAR1A mutations; most of the different mutations in- variably lead to the absence of the R1a protein [156]. However, a small intronic deletion in PRKAR1A that has been identified in CNC patients can also be found in some cases of isolated PPNAD. This mutation also leads to nonsense-mediated decay but is associated with lower penetrance than CNC [180]. In addition, PRKAR1A mutation carriers manifest with myxomas, thyroid tumours, schwannomas and Sertoli cell tumours more frequently 
and generally present earlier than $\mathrm{CNC}$ patients where no PRKAR1A mutations were found [149]. Patients with large deletions of PRKAR1A were suggested to present with CNC at an earlier age (14 vs. 20 years) $[150,179]$.

\section{Conclusions}

The multifactorial and heterogeneous pathogenesis of pituitary tumours is reflected by the multitude of different tumour manifestations in genetic syndromes that also cause PAs, such as MEN1 and CNC. The study of such rare diseases can contribute immensely to the faster diagnosis and better monitoring of affected patients, as reflected by the improvement of MEN1-associated mortality over the last decades. Moreover, the study of MEN syndromes will also aid our understanding of endocrine physiology and tumourigenesis.

Interestingly, PAs are mostly benign and only very rarely acquire malignant properties. MEN1-associated PAs and FIPAs due to AIP mutations are more aggressive than sporadic PAs, with more frequent macroadenomas and a younger age at manifestation in $A I P$-associated
FIPAs $[76,181,182]$. Conversely, pituitary hyperplasia is presumed to precede adenoma formation; an example of this has been observed in an AIP-associated PA [183]. In MAS and CNC, a PAs is rarely observed; however, there are prolonged periods of pituitary hyperplasia in conjunction with abnormal GH, IGF-1 or prolactin levels [160]. Each of these diseases can therefore serve as a model for understanding the steps leading to pituitary tumourigenesis.

For further reading on acromegaly in this issue, see [184-193].

\section{Acknowledgements}

M.H.S.-R. is supported by the Austrian Science Fund (FWF) J-3482. This work was supported mainly by the Intramural Research Program (IRP) of NICHD, NIH.

\section{Disclosure Statement}

The authors have no conflicts of interest to disclose.

\section{References}

-1 Daly AF, Jaffrain-Rea ML, Ciccarelli A, Valdes-Socin H, Rohmer V, Tamburrano G, et al: Clinical characterization of familial isolated pituitary adenomas. J Clin Endocrinol Metab 2006;91:3316-3323.

-2 Scheithauer BW, Laws ER Jr, Kovacs K, Horvath E, Randall RV, Carney JA: Pituitary adenomas of the multiple endocrine neoplasia type I syndrome. Semin Diagn Pathol 1987;4: 205-211.

- 3 Vortmeyer AO, Glasker S, Mehta GU, AbuAsab MS, Smith JH, Zhuang Z, et al: Somatic GNAS mutation causes widespread and diffuse pituitary disease in acromegalic patients with McCune-Albright syndrome. J Clin Endocrinol Metab 2012;97:2404-2413.

-4 Kirschner LS, Carney JA, Pack SD, Taymans SE, Giatzakis C, Cho YS, et al: Mutations of the gene encoding the protein kinase A type I-alpha regulatory subunit in patients with the Carney complex. Nat Genet 2000;26:89-92.

5 Vallar L, Spada A, Giannattasio G: Altered Gs and adenylate cyclase activity in human GHsecreting pituitary adenomas. Nature 1987; 330:566-568.

6 Landis CA, Masters SB, Spada A, Pace AM, Bourne HR, Vallar L: GTPase inhibiting mutations activate the alpha chain of Gs and stimulate adenylyl cyclase in human pituitary tumours. Nature 1989;340:692-696.
7 Landis CA, Harsh G, Lyons J, Davis RL, McCormick F, Bourne HR: Clinical characteristics of acromegalic patients whose pituitary tumors contain mutant Gs protein. J Clin Endocrinol Metab 1990;71:1416-1420.

8 Buchfelder M, Fahlbusch R, Merz T, Symowski H, Adams EF: Clinical correlates in acromegalic patients with pituitary tumors expressing GSP oncogenes. Pituitary 1999;1: 181-185.

$\$ 9$ Freda PU, Chung WK, Matsuoka N, Walsh JE, Kanibir MN, Kleinman G, et al: Analysis of GNAS mutations in 60 growth hormone secreting pituitary tumors: correlation with clinical and pathological characteristics and surgical outcome based on highly sensitive GH and IGF-I criteria for remission. Pituitary 2007;10:275-282.

10 Yamasaki H, Mizusawa N, Nagahiro S, Yamada S, Sano T, Itakura M, et al: GH-secreting pituitary adenomas infrequently contain inactivating mutations of PRKAR1A and $\mathrm{LOH}$ of 17q23-24. Clin Endocrinol (Oxf) 2003;58: 464-470.

11 Levy A, Hall L, Yeudall WA, Lightman SL: p53 gene mutations in pituitary adenomas: rare events. Clin Endocrinol (Oxf) 1994;41: 809-814.

12 Karga HJ, Alexander JM, Hedley-Whyte ET, Klibanski A, Jameson JL: Ras mutations in human pituitary tumors. J Clin Endocrinol Metab 1992;74:914-919.
13 Honda S, Tanaka-Kosugi C, Yamada S, Sano T, Matsumoto T, Itakura M, et al: Human pituitary adenomas infrequently contain inactivation of retinoblastoma 1 gene and activation of cyclin dependent kinase 4 gene. Endocr J 2003;50:309-318

14 Vandeva S, Jaffrain-Rea ML, Daly AF, Tichomirowa $M$, Zacharieva $S$, Beckers A: The genetics of pituitary adenomas. Best Pract Res Clin Endocrinol Metab 2010;24:461-476.

15 Zhuang Z, Ezzat SZ, Vortmeyer AO, Weil R, Oldfield EH, Park WS, et al: Mutations of the MEN1 tumor suppressor gene in pituitary tumors. Cancer Res 1997;57:5446-5451.

16 Evans CO, Brown MR, Parks JS, Oyesiku NM: Screening for MEN1 tumor suppressor gene mutations in sporadic pituitary tumors. J Endocrinol Invest 2000;23:304-309.

17 Korbonits M, Chahal HS, Kaltsas G, Jordan S, Urmanova Y, Khalimova Z, et al: Expression of phosphorylated p27(Kip1) protein and Jun activation domain-binding protein 1 in human pituitary tumors. J Clin Endocrinol Metab 2002;87:2635-2643

18 Prezant TR, Levine J, Melmed S: Molecular characterization of the men1 tumor suppressor gene in sporadic pituitary tumors. J Clin Endocrinol Metab 1998;83:1388-1391. 
19 Newey PJ, Nesbit MA, Rimmer AJ, Head RA, Gorvin CM, Attar M, et al: Whole-exome sequencing studies of nonfunctioning pituitary adenomas. J Clin Endocrinol Metab 2013; 98:E796-E800.

20 Iwata T, Yamada S, Mizusawa N, Golam HM, Sano T, Yoshimoto K: The aryl hydrocarbon receptor-interacting protein gene is rarely mutated in sporadic $\mathrm{GH}$-secreting adenomas. Clin Endocrinol (Oxf) 2007;66:499-502.

-21 Raitila A, Georgitsi M, Karhu A, Tuppurainen K, Makinen MJ, Birkenkamp-Demtroder K, et al: No evidence of somatic aryl hydrocarbon receptor interacting protein mutations in sporadic endocrine neoplasia. Endocr Relat Cancer 2007;14:901-906.

22 DiGiovanni R, Serra S, Ezzat S, Asa SL: AIP Mutations are not identified in patients with sporadic pituitary adenomas. Endocr Pathol 2007;18:76-78.

23 Kaltsas GA, Kola B, Borboli N, Morris DG, Gueorguiev M, Swords FM, et al: Sequence analysis of the PRKAR1A gene in sporadic somatotroph and other pituitary tumours. Clin Endocrinol (Oxf) 2002;57:443-448.

-24 Sandrini F, Kirschner LS, Bei T, Farmakidis C, Yasufuku-Takano J, Takano K, et al: PRKA$\mathrm{R} 1 \mathrm{~A}$, one of the Carney complex genes, and its locus (17q22-24) are rarely altered in pituitary tumours outside the Carney complex. J Med Genet 2002;39:e78.

25 Kasuki L, Vieira Neto L, Wildemberg LE, Colli LM, de Castro M, Takiya CM, et al: AIP expression in sporadic somatotropinomas is a predictor of the response to octreotide LAR therapy independent of SSTR2 expression. Endocr Relat Cancer 2012;19:L25-L29.

-26 Trivellin G, Butz H, Delhove J, Igreja S, Chahal HS, Zivkovic V, et al: MicroRNA miR-107 is overexpressed in pituitary adenomas and inhibits the expression of aryl hydrocarbon receptor-interacting protein in vitro. Am J Physiol Endocrinol Metab 2012;303:E708E719.

27 Denes J, Kasuki L, Trivellin G, Colli LM, Takiya CM, Stiles CE, et al: Regulation of aryl hydrocarbon receptor interacting protein (AIP) protein expression by miR-34a in sporadic somatotropinomas. PLoS One 2015; 10:e0117107.

-28 Toledo RA, Mendonca BB, Fragoso MC, Soares IC, Almeida MQ, Moraes MB, et al: Isolated familial somatotropinoma: $11 \mathrm{q} 13$ loh and gene/protein expression analysis suggests a possible involvement of aip also in non-pituitary tumorigenesis. Clinics (Sao Paulo) 2010;65:407-415

29 Khoo SK, Pendek R, Nickolov R, LuccioCamelo DC, Newton TL, Massie A, et al: Genome-wide scan identifies novel modifier loci of acromegalic phenotypes for isolated familial somatotropinoma. Endocr Relat Cancer 2009;16:1057-1063.

- 30 Longuini VC, Lourenco DM Jr, Sekiya T, Meirelles O, Goncalves TD, Coutinho FL, et al: Association between the p27 rs2066827 variant and tumor multiplicity in patients harboring MEN1 germline mutations. Eur J Endocrinol 2014;171:335-342.

31 de Sanctis C, Lala R, Matarazzo P, Balsamo A, Bergamaschi R, Cappa M, et al: McCune-Albright syndrome: a longitudinal clinical study of 32 patients. J Pediatr Endocrinol Metab 1999;12:817-826.

32 Gadelha MR, Trivellin G, Hernandez Ramirez LC, Korbonits M: Genetics of pituitary adenomas. Front Horm Res 2013;41:111-140.

33 Beckers A, Aaltonen LA, Daly AF, Karhu A: Familial isolated pituitary adenomas (FIPA) and the pituitary adenoma predisposition due to mutations in the aryl hydrocarbon receptor interacting protein (AIP) gene. Endocr Rev 2013;34:239-277.

34 Vierimaa O, Georgitsi M, Lehtonen R, Vahteristo P, Kokko A, Raitila A, et al: Pituitary adenoma predisposition caused by germline mutations in the AIP gene. Science 2006;312:1228-1230.

35 Kantorovich V, King KS, Pacak K: SDH-related pheochromocytoma and paraganglioma. Best Pract Res Clin Endocrinol Metab 2010; 24:415-424.

36 Xekouki P, Pacak K, Almeida M, Wassif CA, Rustin P, Nesterova M, et al: Succinate dehydrogenase (SDH) D subunit (SDHD) inactivation in a growth-hormone-producing pituitary tumor: a new association for $\mathrm{SDH}$ ? J Clin Endocrinol Metab 2012;97:E357E366.

37 Dwight T, Mann K, Benn DE, Robinson BG, McKelvie P, Gill AJ, et al: Familial SDHA mutation associated with pituitary adenoma and pheochromocytoma/paraganglioma. J Clin Endocrinol Metab 2013;98:E1103-E1108.

-38 Lopez-Jimenez E, de Campos JM, Kusak EM, Landa I, Leskela S, Montero-Conde C, et al: SDHC mutation in an elderly patient without familial antecedents. Clin Endocrinol (Oxf) 2008;69:906-910.

39 Xekouki P, Stratakis CA: Succinate dehydrogenase (SDHx) mutations in pituitary tumors: could this be a new role for mitochondrial complex II and/or Krebs cycle defects? Endocr Relat Cancer 2012;19:C33-C40.

40 Denes J, Swords F, Rattenberry E, Stals K, Owens M, Cranston T, et al: Heterogeneous genetic background of the association of pheochromocytoma/paraganglioma and pituitary adenoma - results from a large patient cohort. J Clin Endocrinol Metab 2014, Epub ahead of print.

41 Scheithauer BW, Kovacs K, Horvath E, Kim DS, Osamura RY, Ketterling RP, et al: Pituitary blastoma. Acta Neuropathol 2008;116: 657-666.

42 Scheithauer BW, Horvath E, Abel TW, Robital Y, Park SH, Osamura RY, et al: Pituitary blastoma: a unique embryonal tumor. Pituitary 2012;15:365-373.

43 de Kock L, Sabbaghian N, Plourde F, Srivastava A, Weber E, Bouron-Dal Soglio D, et al: Pituitary blastoma: a pathognomonic feature of germ-line DICER1 mutations. Acta Neuropathol 2014;128:111-122.
44 Trivellin G, Daly AF, Faucz FR, Yuan B, Rostomyan L, Larco DO, et al: Gigantism and Acromegaly Due to Xq26 Microduplications and GPR101 Mutation. N Engl J Med 2014; 371:2363-2374.

45 Josefson J, Listernick R, Fangusaro JR, Charrow J, Habiby R: Growth hormone excess in children with neurofibromatosis type 1-associated and sporadic optic pathway tumors. J Pediatr 2011;158:433-436.

46 Agarwal SK: Multiple endocrine neoplasia type 1. Front Horm Res 2013;41:1-15.

47 Marx S, Spiegel AM, Skarulis MC, Doppman JL, Collins FS, Liotta LA: Multiple endocrine neoplasia type 1: clinical and genetic topics. Ann Intern Med 1998;129:484-494.

48 Kytola S, Villablanca A, Ebeling T, Nord B, Larsson C, Hoog A, et al: Founder effect in multiple endocrine neoplasia type 1 (MEN 1) in Finland. J Med Genet 2001;38:185189.

49 Vierimaa O, Ebeling TM, Kytola S, Bloigu R, Eloranta E, Salmi J, et al: Multiple endocrine neoplasia type 1 in Northern Finland; clinical features and genotype phenotype correlation. Eur J Endocrinol 2007;157:285-294.

50 Trump D, Farren B, Wooding C, Pang JT, Besser GM, Buchanan KD, et al: Clinical studies of multiple endocrine neoplasia type 1 (MEN1). QJM 1996;89:653-669.

51 Bassett JH, Forbes SA, Pannett AA, Lloyd SE Christie PT, Wooding C, et al: Characterization of mutations in patients with multiple endocrine neoplasia type 1 . Am J Hum Genet 1998;62:232-244.

52 Machens A, Schaaf L, Karges W, Frank-Raue K, Bartsch DK, Rothmund M, et al: Age-related penetrance of endocrine tumours in multiple endocrine neoplasia type 1 (MEN1): a multicentre study of 258 gene carriers. Clin Endocrinol (Oxf) 2007;67:613-622.

53 Carty SE, Helm AK, Amico JA, Clarke MR, Foley TP, Watson CG, et al: The variable penetrance and spectrum of manifestations of multiple endocrine neoplasia type 1 . Surgery 1998;124:1106-1113.

54 Doherty GM, Olson JA, Frisella MM, Lairmore TC, Wells SA Jr, Norton JA: Lethality of multiple endocrine neoplasia type I. World J Surg 1998;22:581-586.

55 Goudet P, Murat A, Binquet C, CardotBauters C, Costa A, Ruszniewski P, et al: Risk factors and causes of death in MEN1 disease. A GTE (Groupe d'Etude des Tumeurs Endocrines) cohort study among 758 patients. World J Surg 2010;34:249-255.

56 Dean PG, van Heerden JA, Farley DR, Thompson GB, Grant CS, Harmsen WS, et al: Are patients with multiple endocrine neoplasia type I prone to premature death? World J Surg 2000;24:1437-1441.

57 Twigt BA, Scholten A, Valk GD, Rinkes IH, Vriens MR: Differences between sporadic and MEN related primary hyperparathyroidism; clinical expression, preoperative workup, operative strategy and follow-up. Orphanet J Rare Dis 2013;8:50.
MEN1, MEN4, and Carney Complex:

Pathology and Molecular Genetics
Neuroendocrinology 2016;103:18-31 DOI: $10.1159 / 000371819$ 
58 Eller-Vainicher C, Chiodini I, Battista C, Viti R, Mascia ML, Massironi S, et al: Sporadic and MEN1-related primary hyperparathyroidism: differences in clinical expression and severity. J Bone Miner Res 2009;24:14041410.

-59 Lourenco DM Jr, Coutinho FL, Toledo RA, Montenegro FL, Correia-Deur JE, Toledo SP: Early-onset, progressive, frequent, extensive, and severe bone mineral and renal complications in multiple endocrine neoplasia type 1-associated primary hyperparathyroidism. J Bone Miner Res 2010;25:2382-2391.

-60 Waldmann J, Lopez CL, Langer P, Rothmund M, Bartsch DK: Surgery for multiple endocrine neoplasia type 1-associated primary hyperparathyroidism. Br J Surg 2010;97:15281534.

-61 Arnalsteen LC, Alesina PF, Quiereux JL, Farrel SG, Patton FN, Carnaille BM, et al: Longterm results of less than total parathyroidectomy for hyperparathyroidism in multiple endocrine neoplasia type 1 . Surgery $2002 ; 132$ 1119-1124.

-62 Kraimps JL, Duh QY, Demeure M, Clark OH: Hyperparathyroidism in multiple endocrine neoplasia syndrome. Surgery 1992;112:10801086.

63 Rizzoli R, Green J 3rd, Marx SJ: Primary hyperparathyroidism in familial multiple endocrine neoplasia type I. Long-term follow-up of serum calcium levels after parathyroidectomy. Am J Med 1985;78:467-474.

-64 Salmeron MD, Gonzalez JM, Sancho Insenser J, Goday A, Perez NM, Zambudio AR, et al: Causes and treatment of recurrent hyperparathyroidism after subtotal parathyroidectomy in the presence of multiple endocrine neoplasia 1. World J Surg 2010;34:1325-1331.

65 Thakker RV, Newey PJ, Walls GV, Bilezikian J, Dralle H, Ebeling PR, et al: Clinical practice guidelines for multiple endocrine neoplasia type 1 (MEN1). J Clin Endocrinol Metab 2012;97:2990-3011.

66 Anlauf M, Schlenger R, Perren A, Bauersfeld J, Koch CA, Dralle H, et al: Microadenomatosis of the endocrine pancreas in patients with and without the multiple endocrine neoplasia type 1 syndrome. Am J Surg Pathol 2006;30: 560-574.

-67 Kloppel G, Willemer S, Stamm B, Hacki WH, Heitz PU: Pancreatic lesions and hormonal profile of pancreatic tumors in multiple endocrine neoplasia type I. An immunocytochemical study of nine patients. Cancer 1986;57: 1824-1832.

-68 Akerstrom G, Hessman O, Hellman P, Skogseid B: Pancreatic tumours as part of the MEN-1 syndrome. Best Pract Res Clin Gastroenterol 2005;19:819-830.

-69 Skogseid B, Oberg K, Eriksson B, Juhlin C, Granberg D, Akerstrom G, et al: Surgery for asymptomatic pancreatic lesion in multiple endocrine neoplasia type I. World J Surg 1996;20:872-876; discussion 877.

-70 Berna MJ, Annibale B, Marignani M, Luong TV, Corleto V, Pace A, et al: A prospective study of gastric carcinoids and enterochromaffin-like cell changes in multiple endocrine neoplasia type 1 and Zollinger-Ellison syndrome: identification of risk factors. J Clin Endocrinol Metab 2008;93:1582-1591.

71 Ruszniewski P, Podevin P, Cadiot G, Marmuse JP, Mignon M, Vissuzaine C, et al: Clin$\mathrm{ical}$, anatomical, and evolutive features of patients with the Zollinger-Ellison syndrome combined with type I multiple endocrine neoplasia. Pancreas 1993;8:295-304

72 Pipeleers-Marichal M, Somers G, Willems G, Foulis A, Imrie C, Bishop AE, et al: Gastrinomas in the duodenums of patients with multiple endocrine neoplasia type 1 and the Zollinger-Ellison syndrome. N Engl J Med 1990;322:723-727.

73 Fendrich V, Langer P, Waldmann J, Bartsch DK, Rothmund M: Management of sporadic and multiple endocrine neoplasia type 1 gastrinomas. Br J Surg 2007;94:1331-1341.

74 Triponez F, Dosseh D, Goudet P, Cougard P, Bauters C, Murat A, et al: Epidemiology data on 108 MEN 1 patients from the GTE with isolated nonfunctioning tumors of the pancreas. Ann Surg 2006;243:265-272.

75 Akerstrom G, Hellman P: Surgery on neuroendocrine tumours. Best Pract Res Clin Endocrinol Metab 2007;21:87-109.

76 Verges B, Boureille F, Goudet P, Murat A, Beckers A, Sassolas G, et al: Pituitary disease in MEN type 1 (MEN1): data from the FranceBelgium MEN1 multicenter study. J Clin Endocrinol Metab 2002;87:457-465.

-77 Stratakis CA, Schussheim DH, Freedman SM, Keil MF, Pack SD, Agarwal SK, et al: Pituitary macroadenoma in a 5-year-old: an early expression of multiple endocrine neoplasia type 1. J Clin Endocrinol Metab 2000;85:47764780 .

78 Trouillas J, Labat-Moleur F, Sturm N, Kujas M, Heymann MF, Figarella-Branger D, et al: Pituitary tumors and hyperplasia in multiple endocrine neoplasia type 1 syndrome (MEN1): a case-control study in a series of 77 patients versus 2,509 non-MEN1 patients. Am J Surg Pathol 2008;32:534-543.

79 Daly AF, Tichomirowa MA, Beckers A: The epidemiology and genetics of pituitary adenomas. Best Pract Res Clin Endocrinol Metab 2009;23:543-554.

80 Saleem TF, Santhanam P, Hamoudeh E, Hassan T, Faiz S: Acromegaly caused by growth hormone releasing hormone (GHRH) secreting tumor in multiple endocrine neoplasia (MEN-1). WV Med J 2012;108:26-30.

81 Ramsay JA, Kovacs K, Asa SL, Pike MJ, Thorner MO: Reversible sellar enlargement due to growth hormone-releasing hormone production by pancreatic endocrine tumors in a acromegalic patient with multiple endocrine neoplasia type I syndrome. Cancer 1988; 62:445-450.

82 Shull JD, Birt DF, McComb RD, Spady TJ, Pennington KL, Shaw-Bruha CM: Estrogen induction of prolactin-producing pituitary tumors in the Fischer 344 rat: modulation by dietary-energy but not protein consumption. Mol Carcinog 1998;23:96-105.

83 Gatta-Cherifi B, Chabre O, Murat A, Niccoli P, Cardot-Bauters C, Rohmer V, et al: Adrenal involvement in MEN1. Analysis of 715 cases from the Groupe d'etude des Tumeurs Endocrines database. Eur J Endocrinol 2012;166: 269-279.

84 Darling TN, Skarulis MC, Steinberg SM, Marx SJ, Spiegel AM, Turner M: Multiple facial angiofibromas and collagenomas in patients with multiple endocrine neoplasia type 1. Arch Dermatol 1997;133:853-857.

85 Asgharian B, Turner ML, Gibril F, Entsuah LK, Serrano J, Jensen RT: Cutaneous tumors in patients with multiple endocrine neoplasm type 1 (MEN1) and gastrinomas: prospective study of frequency and development of criteria with high sensitivity and specificity for MEN1. J Clin Endocrinol Metab 2004;89: 5328-5336.

86 van Wijk JP, Dreijerink KM, Pieterman CR, Lips CJ, Zelissen PM, Valk GD: Increased prevalence of impaired fasting glucose in MEN1 gene mutation carriers. Clin Endocrinol (Oxf) 2012;76:67-71

87 McCallum RW, Parameswaran V, Burgess JR: Multiple endocrine neoplasia type 1 (MEN 1) is associated with an increased prevalence of diabetes mellitus and impaired fasting glucose. Clin Endocrinol (Oxf) 2006;65: 163-168.

88 Larsson C, Skogseid B, Oberg K, Nakamura Y, Nordenskjold M: Multiple endocrine neoplasia type 1 gene maps to chromosome 11 and is lost in insulinoma. Nature 1988;332:85-87.

89 Chandrasekharappa SC, Guru SC, Manickam P, Olufemi SE, Collins FS, Emmert-Buck MR, et al: Positional cloning of the gene for multiple endocrine neoplasia-type 1. Science 1997;276:404-407.

90 Lemmens I, Van de Ven WJ, Kas K, Zhang CX, Giraud S, Wautot V, et al: Identification of the multiple endocrine neoplasia type 1 (MEN1) gene. The European Consortium on MEN1. Hum Mol Genet 1997;6:1177-1183.

91 Friedman E, Sakaguchi K, Bale AE, Falchetti A, Streeten E, Zimering MB, et al: Clonality of parathyroid tumors in familial multiple endocrine neoplasia type 1. N Engl J Med 1989;321: 213-218.

92 Thakker RV, Bouloux P, Wooding C, Chotai K, Broad PM, Spurr NK, et al: Association of parathyroid tumors in multiple endocrine neoplasia type 1 with loss of alleles on chromosome 11. N Engl J Med 1989;321:218-224.

93 Wautot V, Khodaei S, Frappart L, Buisson N, Baro E, Lenoir GM, et al: Expression analysis of endogenous menin, the product of the multiple endocrine neoplasia type 1 gene, in cell lines and human tissues. Int J Cancer 2000;85: 877-881

-94 Guru SC, Goldsmith PK, Burns AL, Marx SJ, Spiegel AM, Collins FS, et al: Menin, the product of the MEN1 gene, is a nuclear protein. Proc Natl Acad Sci USA 1998;95:16301634. 
$\$ 95$ La P, Desmond A, Hou Z, Silva AC, Schnepp RW, Hua X: Tumor suppressor menin: the essential role of nuclear localization signal domains in coordinating gene expression. Oncogene 2006;25:3537-3546.

96 Jin S, Mao H, Schnepp RW, Sykes SM, Silva $\mathrm{AC}, \mathrm{D}$ 'Andrea $\mathrm{AD}$, et al: Menin associates with FANCD2, a protein involved in repair of DNA damage. Cancer Res 2003;63:42044210.

$\$ 97$ La P, Silva AC, Hou Z, Wang H, Schnepp RW, Yan N, et al: Direct binding of DNA by tumor suppressor menin. J Biol Chem 2004; 279:49045-49054.

-98 Hughes CM, Rozenblatt-Rosen O, Milne TA, Copeland TD, Levine SS, Lee JC, et al: Menin associates with a trithorax family histone methyltransferase complex and with the hoxc8 locus. Mol Cell 2004;13:587-597.

99 Huang J, Gurung B, Wan B, Matkar S, Veniaminova NA, Wan $\mathrm{K}$, et al: The same pocket in menin binds both MLL and JUND but has opposite effects on transcription. Nature 2012;482:542-546.

100 Busygina V, Kottemann MC, Scott KL, Plon SE, Bale AE: Multiple endocrine neoplasia type 1 interacts with forkhead transcription factor CHES1 in DNA damage response. Cancer Res 2006;66:8397-8403.

101 Agarwal SK, Guru SC, Heppner C, Erdos MR, Collins RM, Park SY, et al: Menin interacts with the AP1 transcription factor JunD and represses JunD-activated transcription. Cell 1999;96:143-152.

102 Kaji H, Canaff L, Lebrun JJ, Goltzman D, Hendy GN: Inactivation of menin, a Smad3interacting protein, blocks transforming growth factor type beta signaling. Proc Natl Acad Sci USA 2001;98:3837-3842.

-103 La P, Schnepp RW, C DP, A CS, Hua X: Tumor suppressor menin regulates expression of insulin-like growth factor binding protein 2. Endocrinology 2004;145:3443-3450.

-104 Heppner C, Bilimoria KY, Agarwal SK, Kester M, Whitty LJ, Guru SC, et al: The tumor suppressor protein menin interacts with NFkappaB proteins and inhibits NF- $\mathrm{kB}$ mediated transactivation. Oncogene 2001; 20:4917-4925.

-105 Inoue Y, Hendy GN, Canaff L, Seino S, Kaji $\mathrm{H}$ : Menin interacts with beta-catenin in osteoblast differentiation. Horm Metab Res 2011;43:183-187.

106 Imachi H, Murao K, Dobashi H, Bhuyan MM, Cao X, Kontani K, et al: Menin, a product of the MENI gene, binds to estrogen receptor to enhance its activity in breast cancer cells: possibility of a novel predictive factor for tamoxifen resistance. Breast Cancer Res Treat 2010;122:395-407.

-107 Dreijerink KM, Mulder KW, Winkler GS, Hoppener JW, Lips CJ, Timmers HT: Menin links estrogen receptor activation to histone H3K4 trimethylation. Cancer Res 2006;66: 4929-4935.

108 Lopez-Egido J, Cunningham J, Berg M, Oberg K, Bongcam-Rudloff E, Gobl A: Me- nin's interaction with glial fibrillary acidic protein and vimentin suggests a role for the intermediate filament network in regulating menin activity. Exp Cell Res 2002;278:175183.

109 Wuescher L, Angevine K, Hinds T, Ramakrishnan S, Najjar SM, Mensah-Osman EJ: Insulin regulates menin expression, cytoplasmic localization, and interaction with FOXO1. Am J Physiol Endocrinol Metab 2011;301:E474-E483.

110 Wang Y, Ozawa A, Zaman S, Prasad NB, Chandrasekharappa SC, Agarwal SK, et al: The tumor suppressor protein menin inhibits AKT activation by regulating its cellular localization. Cancer Res 2011;71:371-382.

111 Kim YS, Burns AL, Goldsmith PK, Heppner C, Park SY, Chandrasekharappa SC, et al: Stable overexpression of MEN1 suppresses tumorigenicity of RAS. Oncogene 1999;18: 5936-5942.

112 Ratineau C, Bernard C, Poncet G, Blanc M, Josso C, Fontaniere S, et al: Reduction of menin expression enhances cell proliferation and is tumorigenic in intestinal epithelial cells. J Biol Chem 2004;279:24477-24484.

113 Schnepp RW, Hou Z, Wang H, Petersen C, Silva A, Masai H, et al: Functional interaction between tumor suppressor menin and activator of S-phase kinase. Cancer Res 2004;64:6791-6796.

114 Schnepp RW, Mao H, Sykes SM, Zong WX, Silva A, La P, et al: Menin induces apoptosis in murine embryonic fibroblasts. J Biol Chem 2004;279:10685-10691.

115 Sayo Y, Murao K, Imachi H, Cao WM, Sato M, Dobashi H, et al: The multiple endocrine neoplasia type 1 gene product, menin, inhibits insulin production in rat insulinoma cells. Endocrinology 2002;143:2437-2440.

116 Busygina V, Suphapeetiporn K, Marek LR, Stowers RS, Xu T, Bale AE: Hypermutability in a Drosophila model for multiple endocrine neoplasia type 1. Hum Mol Genet 2004;13:2399-2408.

117 Milne TA, Hughes CM, Lloyd R, Yang Z, Rozenblatt-Rosen O, Dou Y, et al: Menin and MLL cooperatively regulate expression of cyclin-dependent kinase inhibitors. Proc Natl Acad Sci USA 2005;102:749-754.

118 Yokoyama A, Wang Z, Wysocka J, Sanyal M, Aufiero DJ, Kitabayashi I, et al: Leukemia proto-oncoprotein MLL forms a SET1-like histone methyltransferase complex with menin to regulate Hox gene expression. Mol Cell Biol 2004;24:5639-5649.

119 Yokoyama A, Somervaille TC, Smith KS, Rozenblatt-Rosen O, Meyerson M, Cleary ML: The menin tumor suppressor protein is an essential oncogenic cofactor for MLL-associated leukemogenesis. Cell 2005;123: 207-218.

120 Lemos MC, Thakker RV: Multiple endocrine neoplasia type 1 (MEN1): analysis of 1,336 mutations reported in the first decade following identification of the gene. Hum Mutat 2008;29:22-32.
121 Yaguchi H, Ohkura N, Takahashi M, Nagamura Y, Kitabayashi I, Tsukada T: Menin missense mutants associated with multiple endocrine neoplasia type 1 are rapidly degraded via the ubiquitin-proteasome pathway. Mol Cell Biol 2004;24: 6569-6580.

122 Luzi E, Marini F, Tognarini I, Carbonell Sala S, Galli G, Falchetti A, et al: Ribozyme-mediated compensatory induction of meninoncosuppressor function in primary fibroblasts from MEN1 patients. Cancer Gene Ther 2010;17:814-825.

123 Turner JJ, Leotlela PD, Pannett AA, Forbes SA, Bassett JH, Harding B, et al: Frequent occurrence of an intron 4 mutation in multiple endocrine neoplasia type 1. J Clin Endocrinol Metab 2002;87:2688-2693.

124 Nagamura Y, Yamazaki M, Shimazu S, Sano K, Tsukada T, Sakurai A: A novel splice site mutation of the MEN1 gene identified in a patient with primary hyperparathyroidism. Endocr J 2012;59:523-530.

125 Lemos MC, Harding B, Shalet SM, Thakker RV: A novel MEN1 intronic mutation associated with multiple endocrine neoplasia type 1. Clin Endocrinol (Oxf) 2007;66:709713.

126 Ellard S, Hattersley AT, Brewer CM, Vaidya B: Detection of an MEN1 gene mutation depends on clinical features and supports current referral criteria for diagnostic molecular genetic testing. Clin Endocrinol (Oxf) 2005;62:169-175.

127 Klein RD, Salih S, Bessoni J, Bale AE: Clinical testing for multiple endocrine neoplasia type 1 in a DNA diagnostic laboratory. Genet Med 2005;7:131-138.

128 Burgess JR, Nord B, David R, Greenaway TM, Parameswaran V, Larsson C, et al: Phenotype and phenocopy: the relationship between genotype and clinical phenotype in a single large family with multiple endocrine neoplasia type 1 (MEN 1). Clin Endocrinol (Oxf) 2000;53:205-211.

129 Owens M, Ellard S, Vaidya B: Analysis of gross deletions in the MEN1 gene in patients with multiple endocrine neoplasia type 1 . Clin Endocrinol (Oxf) 2008;68:350-354.

130 Tham E, Grandell U, Lindgren E, Toss G, Skogseid B, Nordenskjold M: Clinical testing for mutations in the MEN1 gene in Sweden: a report on 200 unrelated cases. J Clin Endocrinol Metab 2007;92:3389-3395.

131 Kouvaraki MA, Lee JE, Shapiro SE, Gagel RF, Sherman SI, Sellin RV, et al: Genotypephenotype analysis in multiple endocrine neoplasia type 1 . Arch Surg 2002;137:641647.

132 Bartsch DK, Langer P, Wild A, Schilling T, Celik I, Rothmund M, et al: Pancreaticoduodenal endocrine tumors in multiple endocrine neoplasia type 1: surgery or surveillance? Surgery 2000;128:958-966.

133 Thakker RV: Multiple endocrine neoplasia - syndromes of the twentieth century. J Clin Endocrinol Metab 1998;83:2617-2620.
MEN1, MEN4, and Carney Complex: Pathology and Molecular Genetics
Neuroendocrinology 2016;103:18-31 DOI: $10.1159 / 000371819$ 
134 Flanagan DE, Armitage M, Clein GP, Thakker RV: Prolactinoma presenting in identical twins with multiple endocrine neoplasia type 1. Clin Endocrinol (Oxf) 1996;45:117120.

135 Namihira H, Sato M, Miyauchi A, Ohye H, Matsubara S, Bhuiyan MM, et al: Different phenotypes of multiple endocrine neoplasia type 1 (MEN1) in monozygotic twins found in a Japanese MEN1 family with MEN1 gene mutation. Endocr J 2000;47:37-43.

136 Concolino P, Rossodivita A, Carrozza C, Raffaelli M, Lombardi CP, Rigante D, et al: A novel MEN1 frameshift germline mutation in two Italian monozygotic twins. Clin Chem Lab Med 2008;46:824-826.

-137 Lips CJ, Dreijerink KM, Hoppener JW: Variable clinical expression in patients with a germline MEN1 disease gene mutation: clues to a genotype-phenotype correlation. Clinics (Sao Paulo) 2012;67(suppl 1):49-56.

-138 Pellegata NS, Quintanilla-Martinez L, Siggelkow H, Samson E, Bink K, Hofler H, et al: Germ-line mutations in p27Kip1 cause a multiple endocrine neoplasia syndrome in rats and humans. Proc Natl Acad Sci USA 2006; 103:15558-15563.

139 Karnik SK, Hughes CM, Gu X, RozenblattRosen O, McLean GW, Xiong Y, et al: Menin regulates pancreatic islet growth by promoting histone methylation and expression of genes encoding p27Kipl and p18INK4c. Proc Natl Acad Sci USA 2005;102:1465914664.

140 James MK, Ray A, Leznova D, Blain SW: Differential modification of p27Kip1 controls its cyclin D-cdk4 inhibitory activity. Mol Cell Biol 2008;28:498-510.

-141 Donovan JC, Milic A, Slingerland JM: Constitutive MEK/MAPK activation leads to p27(Kip1) deregulation and antiestrogen resistance in human breast cancer cells. J Biol Chem 2001;276:40888-40895.

142 Andreu EJ, Lledo E, Poch E, Ivorra C, Albero MP, Martinez-Climent JA, et al: BCR$\mathrm{ABL}$ induces the expression of Skp2 through the PI3K pathway to promote p27Kip1 degradation and proliferation of chronic myelogenous leukemia cells. Cancer Res 2005; 65:3264-3272.

143 Agarwal SK, Mateo CM, Marx SJ: Rare germline mutations in cyclin-dependent kinase inhibitor genes in multiple endocrine neoplasia type 1 and related states. J Clin Endocrinol Metab 2009;94:1826-1834.

144 Molatore S, Marinoni I, Lee M, Pulz E, Ambrosio MR, degli Uberti EC, et al: A novel germline CDKN1B mutation causing multiple endocrine tumors: clinical, genetic and functional characterization. Hum Mutat 2010;31:E1825-E1835.

-145 Malanga D, De Gisi S, Riccardi M, Scrima M, De Marco C, Robledo M, et al: Functional characterization of a rare germline mutation in the gene encoding the cyclin-dependent kinase inhibitor p27Kip1 (CDKN1B) in a
Spanish patient with multiple endocrine neoplasia-like phenotype. Eur J Endocrinol 2012;166:551-560.

146 Occhi G, Regazzo D, Trivellin G, Boaretto F, Ciato D, Bobisse S, et al: A novel mutation in the upstream open reading frame of the $\mathrm{CD}$ KN1B gene causes a MEN4 phenotype. PLoS Genet 2013;9:e1003350.

147 Pellegata NS: MENX and MEN4. Clinics (Sao Paulo) 2012;67(suppl 1):13-18.

148 Georgitsi M, Raitila A, Karhu A, van der Luijt RB, Aalfs CM, Sane T, et al: Germline CDKN1B/p27Kip1 mutation in multiple endocrine neoplasia. J Clin Endocrinol Metab 2007;92:3321-3325.

149 Bertherat J, Horvath A, Groussin L, Grabar S, Boikos S, Cazabat L, et al: Mutations in regulatory subunit type $1 \mathrm{~A}$ of cyclic adenosine $5^{\prime}$-monophosphate-dependent protein kinase (PRKAR1A): phenotype analysis in 353 patients and 80 different genotypes. J Clin Endocrinol Metab 2009;94: 2085-2091.

150 Stratakis CA, Kirschner LS, Carney JA: Clinical and molecular features of the Carney complex: diagnostic criteria and recommendations for patient evaluation. J Clin Endocrinol Metab 2001;86:4041-4046.

151 Carney JA, Hruska LS, Beauchamp GD, Gordon H: Dominant inheritance of the complex of myxomas, spotty pigmentation, and endocrine overactivity. Mayo Clin Proc 1986;61:165-172.

152 Carney JA, Gordon H, Carpenter PC, Shenoy BV, Go VL: The complex of myxomas, spotty pigmentation, and endocrine overactivity. Medicine (Baltimore) 1985;64:270283.

153 Stergiopoulos SG, Stratakis CA: Human tumors associated with Carney complex and germline PRKAR1A mutations: a protein kinase A disease! FEBS Lett 2003;546: 59-64.

154 Atherton DJ, Pitcher DW, Wells RS, MacDonald DM: A syndrome of various cutaneous pigmented lesions, myxoid neurofibromata and atrial myxoma: the NAME syndrome. Br J Dermatol 1980;103:421-429.

-155 Rhodes AR, Silverman RA, Harrist TJ, Perez-Atayde AR: Mucocutaneous lentigines, cardiomucocutaneous myxomas, and multiple blue nevi: the 'LAMB' syndrome. J Am Acad Dermatol 1984;10:72-82.

156 Kirschner LS, Sandrini F, Monbo J, Lin JP, Carney JA, Stratakis CA: Genetic heterogeneity and spectrum of mutations of the PRKAR1A gene in patients with the carney complex. Hum Mol Genet 2000;9:30373046.

157 Stratakis CA, Sarlis N, Kirschner LS, Carney JA, Doppman JL, Nieman LK, et al: Paradoxical response to dexamethasone in the diagnosis of primary pigmented nodular adrenocortical disease. Ann Intern Med 1999;131: 585-591.

158 Raff SB, Carney JA, Krugman D, Doppman JL, Stratakis CA: Prolactin secretion abnor- malities in patients with the 'syndrome of spotty skin pigmentation, myxomas, endocrine overactivity and schwannomas' (Carney complex). J Pediatr Endocrinol Metab 2000;13:373-379.

159 Watson JC, Stratakis CA, Bryant-Greenwood PK, Koch CA, Kirschner LS, Nguyen $\mathrm{T}$, et al: Neurosurgical implications of Carney complex. J Neurosurg 2000;92:413418.

160 Pack SD, Kirschner LS, Pak E, Zhuang Z, Carney JA, Stratakis CA: Genetic and histologic studies of somatomammotropic pituitary tumors in patients with the 'complex of spotty skin pigmentation, myxomas, endocrine overactivity and schwannomas' (Carney complex). J Clin Endocrinol Metab 2000;85:3860-3865.

161 Stratakis CA, Matyakhina L, Courkoutsakis N, Patronas N, Voutetakis A, Stergiopoulos $S$, et al: Pathology and molecular genetics of the pituitary gland in patients with the 'complex of spotty skin pigmentation, myxomas, endocrine overactivity and schwannomas (Carney complex). Front Horm Res 2004;32: 253-264.

162 Stergiopoulos SG, Abu-Asab MS, Tsokos M, Stratakis CA: Pituitary pathology in Carney complex patients. Pituitary 2004;7:73-82.

163 Stratakis CA, Papageorgiou T, Premkumar A, Pack S, Kirschner LS, Taymans SE, et al: Ovarian lesions in Carney complex: clinical genetics and possible predisposition to malignancy. J Clin Endocrinol Metab 2000;85: 4359-4366.

164 Gennari M, Stratakis CA, Horvath A, Pirazzoli P, Cicognani A: A novel PRKAR1A mutation associated with hepatocellular carcinoma in a young patient and a variable Carney complex phenotype in affected subjects in older generations. Clin Endocrinol (Oxf) 2008;69:751-755.

165 Gaujoux S, Tissier F, Ragazzon B, Rebours V, Saloustros E, Perlemoine K, et al: Pancreatic ductal and acinar cell neoplasms in Carney complex: a possible new association. J Clin Endocrinol Metab 2011;96:E1888E1895.

166 Veugelers M, Wilkes D, Burton K, McDermott DA, Song Y, Goldstein MM, et al: Comparative PRKAR1A genotype-phenotype analyses in humans with Carney complex and prkarla haploinsufficient mice. Proc Natl Acad Sci USA 2004;101:1422214227.

167 Bossis I, Stratakis CA: Minireview: PRKAR1A: normal and abnormal functions. Endocrinology 2004;145:5452-5458.

168 Yu B, Ragazzon B, Rizk-Rabin M, Bertherat $\mathrm{J}$ : Protein kinase A alterations in endocrine tumors. Horm Metab Res 2012;44:741-748.

169 Robinson-White A, Meoli E, Stergiopoulos S, Horvath A, Boikos S, Bossis I, et al: PRKAR1A Mutations and protein kinase A interactions with other signaling pathways in the adrenal cortex. J Clin Endocrinol Metab 2006;91:2380-2388. 
170 Groussin L, Kirschner LS, Vincent-Dejean C, Perlemoine K, Jullian E, Delemer B, et al: Molecular analysis of the cyclic AMP-dependent protein kinase $\mathrm{A}$ (PKA) regulatory subunit 1A (PRKAR1A) gene in patients with Carney complex and primary pigmented nodular adrenocortical disease (PPNAD) reveals novel mutations and clues for pathophysiology: augmented PKA signaling is associated with adrenal tumorigenesis in PPNAD. Am J Hum Genet 2002;71:1433-1442.

171 Horvath A, Bossis I, Giatzakis C, Levine E, Weinberg F, Meoli E, et al: Large deletions of the PRKAR1A gene in Carney complex. Clin Cancer Res 2008;14:388-395.

172 Ragazzon B, Cazabat L, Rizk-Rabin M, Assie G, Groussin L, Fierrard H, et al: Inactivation of the Carney complex gene 1 (protein kinase A regulatory subunit $1 \mathrm{~A}$ ) inhibits SMAD3 expression and TGF beta-stimulated apoptosis in adrenocortical cells. Cancer Res 2009;69:7278-7284.

173 Robinson-White AJ, Leitner WW, Aleem E, Kaldis P, Bossis I, Stratakis CA: PRKAR1A inactivation leads to increased proliferation and decreased apoptosis in human B lymphocytes. Cancer Res 2006;66:10603-10612.

174 Robinson-White A, Hundley TR, Shiferaw M, Bertherat J, Sandrini F, Stratakis CA: Protein kinase-A activity in PRKAR1A-mutant cells, and regulation of mitogen-activated protein kinases ERK1/2. Hum Mol Genet 2003; 12:1475-1484.

175 Almeida MQ, Muchow M, Boikos S, Bauer AJ, Griffin KJ, Tsang KM, et al: Mouse Prkarla haploinsufficiency leads to an increase in tumors in the Trp53+/- or Rb1+/- backgrounds and chemically induced skin papillomas by dysregulation of the cell cycle and Wnt signaling. Hum Mol Genet 2010;19: 1387-1398.
176 Tsang KM, Starost MF, Nesterova M, Boikos SA, Watkins T, Almeida MQ, et al: Alternate protein kinase $A$ activity identifies a unique population of stromal cells in adult bone. Proc Natl Acad Sci USA 2010;107:86838688.

177 Tadjine M, Lampron A, Ouadi L, Horvath A, Stratakis CA, Bourdeau I: Detection of somatic beta-catenin mutations in primary pigmented nodular adrenocortical disease (PPNAD). Clin Endocrinol (Oxf) 2008;69: 367-373.

178 Gaujoux S, Tissier F, Groussin L, Libe R, Ragazzon B, Launay P, et al: Wnt/betacatenin and $3^{\prime}, 5^{\prime}$-cyclic adenosine $5^{\prime}$-monophosphate/protein kinase A signaling pathways alterations and somatic beta-catenin gene mutations in the progression of adrenocortical tumors. J Clin Endocrinol Metab 2008;93:4135-4140.

179 Salpea P, Horvath A, London E, Faucz FR, Vetro A, Levy I, et al: Deletions of the PRKAR1A locus at 17q24.2-q24.3 in Carney complex: genotype-phenotype correlations and implications for genetic testing. J Clin Endocrinol Metab 2014;99:E183-E188.

180 Groussin L, Horvath A, Jullian E, Boikos S, Rene-Corail F, Lefebvre H, et al: A PRKAR1A mutation associated with primary pigmented nodular adrenocortical disease in 12 kindreds. J Clin Endocrinol Metab 2006;91: 1943-1949.

181 Cuny T, Pertuit M, Sahnoun-Fathallah M, Daly A, Occhi G, Odou MF, et al: Genetic analysis in young patients with sporadic pituitary macroadenomas: besides AIP don't forget MEN1 genetic analysis. Eur J Endocrinol 2013;168:533-541.

182 Daly AF, Tichomirowa MA, Petrossians P, Heliovaara E, Jaffrain-Rea ML, Barlier A, et al: Clinical characteristics and therapeutic responses in patients with germ-line AIP mutations and pituitary adenomas: an international collaborative study. J Clin Endocrinol Metab 2010;95:E373-E383.
83 Villa C, Lagonigro MS, Magri F, Koziak M, Jaffrain-Rea ML, Brauner R, et al: Hyperplasia-adenoma sequence in pituitary tumourigenesis related to aryl hydrocarbon receptor interacting protein gene mutation. Endocr Relat Cancer 2011;18:347-356.

184 de Herder WW: The history of acromegaly. Neuroendocrinology 2016;103:7-17.

185 Buchfelder M, Schlaffer S-M: Novel techniques in the surgical treatment of acromegaly: applications and efficacy. Neuroendocrinology 2016;103:32-41.

186 Hannon MJ, Barkan AL, Drake WM: The role of radiotherapy in acromegaly. Neuroendocrinology 2016;103:42-49.

187 Chanson P: Medical treatment of acromegaly with dopamine agonists or somatostatin analogs. Neuroendocrinology 2016;103:50-58.

188 Neggers SJCMM, Muhammad A, van der Lely AJ: Pegvisomant treatment in acromegaly. Neuroendocrinology 2016;103:59-65.

189 McCabe J, Ayuk J, Sherlock M: Treatment factors that influence mortality in acromegaly. Neuroendocrinology 2016;103:66-74.

190 Powlson AS, Gurnell M: Cardiovascular disease and sleep-disordered breathing in acromegaly. Neuroendocrinology 2016;103:7585.

191 Claessen KMJA, Mazziotti G, Biermasz NR, Giustina A: Bone and joint disorders in acromegaly. Neuroendocrinology 2016;103:8695.

192 Dal J, List EO, Jørgensen JOL, Berryman DE: Glucose and fat metabolism in acromegaly: from mice models to patient care. Neuroendocrinology 2016;103:96-05.

193 Webb SM, Badia X: Quality of life in acromegaly. Neuroendocrinology 2016;103:106111.
MEN1, MEN4, and Carney Complex: Pathology and Molecular Genetics
Neuroendocrinology 2016;103:18-31 DOI: $10.1159 / 000371819$ 